\begin{tabular}{c} 
Brazilian Journal \\
of Chemical \\
Engineering \\
\hline
\end{tabular}

Vol. 35, No. 03, pp. 909-918, July - September, 2018

dx.doi.org/10.1590/0104-6632.20180353s20170156

\title{
ULTRASONIC PRE-TREATMENT OF WASTEWATER SLUDGE FROM A MEAT PROCESSING INDUSTRY
}

\author{
Ayse Filibeli ${ }^{1}$, Gulbin Erden ${ }^{2, *}$ and Cimen Gunduz ${ }^{1}$ \\ ${ }^{1}$ Dokuz Eylül University, Department of Environmental Engineering, Tinaztepe \\ Campus, 35160, Buca-Izmir, Turkey \\ ${ }^{2}$ Pamukkale University, Department of Environmental Engineering, Kinikli \\ Campus, Denizli, Turkey
}

(Submitted: March 21, 2017; Revised: June 1, 2017; Accepted: June 11, 2017)

\begin{abstract}
This investigation deals with ultrasonic disintegration of sludge taken from a meat processing wastewater treatment plant. Different specific energy inputs ranging between 0 and $100 \mathrm{MJ} / \mathrm{kg}$ Total Solids (TS) were used in the study. The effect of ultrasonic pre-treatment on anaerobic biodegradability and filterability characteristics of sludge were evaluated using lab-scale experiments. $30 \mathrm{MJ} / \mathrm{kg}$ TS of supplied energy is efficient for cell lyses. Ultrasonic pre-treatment significantly enhanced the biodegradability of sludge. Biochemical methane potential test results also supported this result. For $30 \mathrm{MJ} / \mathrm{kg}$ TS, 2.4 times higher methane production was achieved compared to raw sludge. Sludge's supernatant characteristics were also affected by the ultrasonic pre-treatment. For $30 \mathrm{MJ} / \mathrm{kg} \mathrm{TS}$, oil content, total nitrogen and total phosphorus in the sludge supernatant increased by 3.8 times, 58 times, and 12 times, respectively. The other result is that ultrasonic treatment adversely affected filterability characteristics of sludge even for very low specific energy levels.
\end{abstract}

Keywords: Anaerobic biodegradability; Biochemical methane potential; Filterability; Floc disintegration; Meat processing wastewater.

\section{INTRODUCTION}

Meat industry wastes have a very complex composition and, to optimize the biological treatment conditions, it is necessary to make a thorough analysis of these organic wastes in terms of their different biodegradable fractions and degradation kinetics. Many of these wastes are solids and either not biodegradable or very slow to degrade in biological processes (Rico et al. (2007)). Sludge produced in the treatment units is also a big problem due to the non-bio-degradable fractions and lipid-rich materials contained. Lipid-rich materials have high methane production potential, but their degradation products, long chain fatty acids (LCFAs), can be inhibitive in high concentrations. LCFA inhibition was long believed to be irreversible, but recent studies have shown the contrary, though recovery takes a long time. Pre-treating organic materials prior to anaerobic digestion aims at enhanced hydrolysis and thus more complete degradation, as bacterial cells are only able to uptake small molecules (Luste et al., 2009). Current technologies for oily sludge treatment, such as solidification, chemical heat treatment, and extraction, are either costly or ineffective. Therefore, oily sludge is not being disposed of properly (Ning et al., 2009). 
Disintegration was developed as pre-treatment of organic materials prior to anaerobic digestion of sludge to enhance hydrolysis and to complete degradation. Ultrasonic energy can be applied as pre-treatment to disintegrate sludge flocks and disrupt bacterial cell walls, and the hydrolysis can be improved, so that the rate of sludge digestion and methane production is improved (Wang et al., 2005). Ultrasound treatment for sludge disintegration results in increase of chemical oxygen demand in the sludge supernatant and size reduction of sludge solids (Tiehm et al., 1997). The ultrasonic process leads to cavitation bubble formation in the liquid phase. These bubbles grow and then violently collapse when they reach a critical size. Cavitational collapse produces intense local heating and high pressure at the liquid-gas interface, turbulence and high shearing phenomena in the liquid phase. Because of the extreme local conditions, $\mathrm{OH} \bullet, \mathrm{HO}_{2}$, $\mathrm{H} \bullet$ radicals and hydrogen peroxide can be formed. Thus, three mechanisms (hydro-chemical shear forces, thermal decomposition of volatile hydrophobic substances in the sludge, and oxidizing effects of free radicals produced under the ultrasonic radiation are responsible for the sludge disintegration (Wang, 2005; Riesz et al., 1985; Bougrier et al., 2005). Although the effects of ultrasonic pre-treatment (Show et al., 2007); Pham et al. (2009); Xie et al. (2009); Huan et al. (2009); Erden and Filibeli (2010); u et al., 2011; Anteneh et al., 2013; Zhou et al., 2016; Zielewicz, 2016) and its combinations with other methods (Sahinkaya, 2015; Xinbo et al., 2015; Yeneneh et al., 2015; Kavitha et al., 2016; Yeneneh et al., 2017) on activated sludge disintegration were investigated by several researchers, there are very limited studies on ultrasonic pre-treatment of meat processing sludge (Luste et al., 2009; Ning et al., 2009). The results of previous studies showed that ultrasonic pretreatment is an effective method for waste activated sludge processing. To our knowledge, ultrasonic pretreatment has not been applied to sludge taken from a meat processing wastewater treatment plant.

Even though ultrasonic pretreatments for sludge minimization and biogas production have been studied widely, no previous research has been conducted to test the effectiveness of ultrasonic pretreatment for meat processing wastewater sludge. Therefore, the main objective of this study was to investigate the effect of ultrasonic pretreatment as a physical method for improving anaerobic digestion of meat processing wastewater sludge. Besides, the effect of ultrasonic pre-treatment on filterability characteristics of sludge was evaluated using lab-scale experiments.

\section{MATERIALS AND METHODS}

\section{Sludge}

Meat processing sludge was sampled from a local meat processing plant in Izmir, Turkey. The samples were taken from the sludge collection basin of the secondary clarifier. The properties of meat processing sludge are given in Table 1. All analysis was done according to procedures given in Standard Methods (APHA 2005) and was repeated three times. The values represent the mean of the measurements.

\section{Ultrasonic pre-treatment}

The ultrasonic apparatus was a Sonopuls ultrasonic homogenizer (Bandelin- Sonopuls HD 2200). This apparatus was equipped with a VS $70 \mathrm{~T}$ probe with an operating frequency of $20 \mathrm{kHz}$ and a supplied power of $200 \mathrm{~W}$. For each experiment, $500 \mathrm{~mL}$ of sludge were filled in a glass beaker without temperature adjustment (no cooling) and the ultrasonic probe was submerged into the sludge-containing beaker to the depth of $2 \mathrm{~cm}$

Table 1. Properties of meat processing sludge.

\begin{tabular}{lc}
\hline Parameters & Average Value \\
\hline $\mathrm{pH}$ & 7.29 \\
$\mathrm{TS}$ (Total Solids Content), $\%$ & 1.1 \\
VS (Volatile Solids Content), $\%$ & 76 \\
$\mathrm{SS}$ (Suspended Solids Content), $\mathrm{mg} / \mathrm{L}$ & 10520 \\
VSS (Volatile Suspended Solids Content), mg/L & 9100 \\
Oil content in the sludge supernatant, $\mathrm{mg} / \mathrm{L}$ & 19478 \\
$\mathrm{SCOD}$ (Soluble Chemical Oxygen Demand), mg/L & 880 \\
TN (Total Nitrogen in supernatant), $\mathrm{mg} / \mathrm{L}$ & 9 \\
TP (Total Phosphorus in supernatant), $\mathrm{mg} / \mathrm{L}$ & 4.8 \\
Protein, mg/L & 2530.6 \\
Capillary Suction Time, $\mathrm{s}$ & 14.5 \\
\hline
\end{tabular}


above the bottom of the beaker. Specific energy was considered as a main variable parameter for evaluation of the disintegration performance of sludge. Ultrasonic time varied from 1 to $60 \mathrm{~min}$. SE was determined by using ultrasonic power $(\mathrm{P})$, ultrasonic time $(\mathrm{t})$, sample volume $(\mathrm{V})$ and initial total solid concentration $\left(\mathrm{TS}_{0}\right)$ according to the following equation (Bougrier et al., 2006):

$\mathrm{SE}(\mathrm{kJ} / \mathrm{kg} \mathrm{TS})=\mathrm{P}(\mathrm{W}) \times \mathrm{t}(\mathrm{s}) / \mathrm{V}(\mathrm{L}) \times \mathrm{TS}_{0}(\mathrm{~g} / \mathrm{L})$

\section{Biochemical methane potential (BMP) assay}

The effect of ultrasonic pre-treatment on anaerobic biodegradability of meat processing sludge was evaluated based on the BMP assay (Owen et al, 1979). The BMP test was applied to both raw and sonicated samples (S) for comparison purposes. Anaerobic stock culture was used as inoculums (I). The culture was obtained from an upflow anaerobic sludge blanket bioreactor (UASB) unit of Efes Brewery Industry in Izmir, Turkey. The stock basal medium (BM) was prepared in distilled water (Speece, 1996). BMP tests were carried out in $150 \mathrm{~mL}$ serum bottles with $60 \mathrm{~mL}$ reaction volume. The ratio of basal medium/ inoculums/sludge in the BMP test was BM/I/S=0.5/1/1 $(\mathrm{v} / \mathrm{v})$. All bottles were purged with $75 \% \mathrm{~N}_{2}$ and 25 $\% \mathrm{CO}_{2}$ containing gas mixture for 3-4 min to obtain anaerobic conditions. Rubber stoppers and screw caps were used to avoid gas leakage from the bottles. The serum bottles were placed in an incubator at constant temperature of $37 \pm 2{ }^{\circ} \mathrm{C}$. Methane gas productions were measured daily by the liquid displacement method using $3 \% \mathrm{NaOH}(\mathrm{w} / \mathrm{v})$ containing distilled water (Razo-Flores et al., 1997). Anaerobic digestion performances of the sludges were evaluated from the methane productions in the bottles. High methane productions in the bottles indicated high anaerobic digestion performances of the sludge samples.

\section{Analytical procedures}

The disintegration degree (Muller, 2000) parameter based on soluble COD calculations was considered as the main parameter for evaluation of sludge disintegration. The soluble part of sludge was obtained by centrifugation carried out at $15000 \mathrm{rpm}$ and $4^{\circ} \mathrm{C}$ for $20 \mathrm{~min}$. TS and VS were measured according to the procedure given in Standard Methods (APHA, 2005). Total nitrogen (TN) and total phosphorus (TP) in the sludge supernatant were measured using spectroquant Merck kits numbered 14537, and 00616, respectively, in a NOVA 60 photometer. Particle size distributions of sludge were monitored using a Malvern Mastersizer 2000QM analyzer. Capillary Suction Time (CST) values were analyzed with a Triton A-304 M CSTmeter. Volatile fatty acid (VFA) measurements were done using an Agilent 1100 HPLC with C18 column. Extracellular polymeric substances (EPS) were extracted from the samples using the heat extraction technique (Goodwin and Forster, 1985; Frolund et al., 1996).

\section{RESULTS AND DISCUSSION}

\section{The effects of ultrasonic treatment on disintegra- tion degree of sludge}

The disintegration degree (DD) permits evaluation of the maximum level of sludge solubilization. Increase of DD is determined as the substance that can be readily used to produce methane in the anaerobic digestion (Wang et al., 2005). DD of sonicated sludge increased with increasing specific energy in each experiment (Fig. 1). For specific energy under $10 \mathrm{MJ} / \mathrm{kg} \mathrm{TS}$, the disintegration degree was low (3.5 \% for $5 \mathrm{MJ} / \mathrm{kg} \mathrm{TS}$ ). Maximum disintegration degree of $47.4 \%$ was obtained for a specific energy of $30 \mathrm{MJ} / \mathrm{kg}$ TS. Ultrasonic time was $40 \mathrm{~min}$ in this application, so $40 \mathrm{~min}$ ultrasonic duration and $30 \mathrm{MJ} /$ $\mathrm{kg}$ TS specific energy were considered as optimum for meat processing sludge. Sludge taken from the meat processing wastewater treatment plant required higher SE levels than biological sludge to reach maximum DD value (Bougrier et al., 2005; Erden and Filibeli, 2010). The lower solubilization levels in our study can be attributed to the sludge composition. Sludge taken from the meat processing wastewater treatment plant contains non bio-degradable fractions and lipid-rich materials different from the biological sludge. For specific energies above $30 \mathrm{MJ} / \mathrm{kg}$ TS, DD decreased.

Decrease of the DD may be explained by the high oxidation effects of radicals. Up to $30 \mathrm{MJ} /$ $\mathrm{kg} \mathrm{TS}$, hydroxyl radicals preferentially attack the organic substances and destroy the activated sludge microorganism's cell walls in biomass and oxidize them to dissolve organic substances and these substances are released to the liquid phase and increase the DD. For specific energies above $30 \mathrm{MJ} / \mathrm{kg} \mathrm{TS}$, as SE increases, more soluble organics were mineralized and DD decreased. 


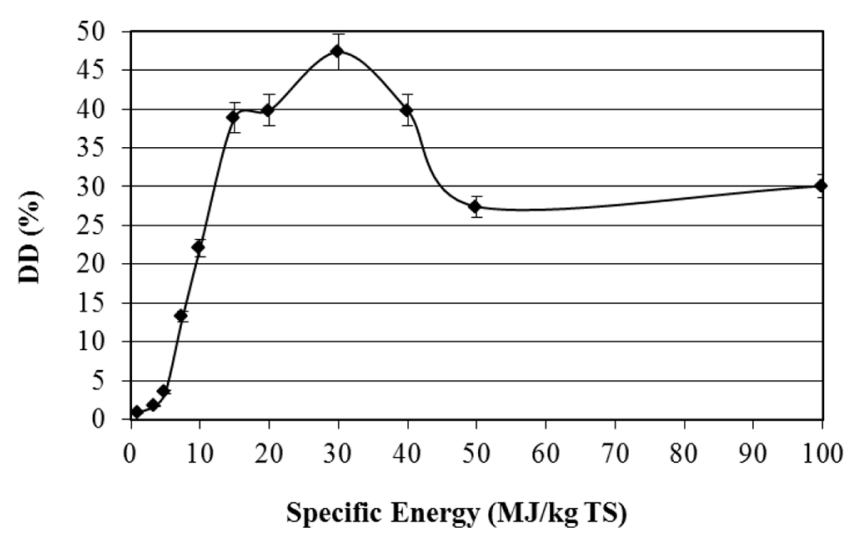

Figure 1. Variation of disintegration degree with specific energy

\section{Changes in physico-chemical characteristics of sludge}

Ultrasonic treatment led to a change of the physicochemical characteristics of sludge. For instance, temperature increased almost linearly with increasing specific energy (Fig. 2). Temperature increased from $20^{\circ} \mathrm{C}$ in raw sludge to $84^{\circ} \mathrm{C}$ for ultrasonic pre-treated sludge with maximum specific energy input of 100 $\mathrm{MJ} / \mathrm{kg}$ TS. The rise of temperature helps ultrasonic disintegration. On the other hand, the high increase in temperature leads to higher saturated vapor pressures, which makes it harder for vapor bubbles to collapse and thus decreases the intensity of cavitation (Huan et al., 2009). One of the reasons for the decreasing DD above $30 \mathrm{MJ} / \mathrm{kg}$ TS may be high temperatures. In contrast, $\mathrm{pH}$ decreased during ultrasonic pre-treatment (Fig. 2). It decreased from 7.3 in raw sludge to 6.3 for ultrasonic pre-treated sludge at $100 \mathrm{MJ} / \mathrm{kg} \mathrm{TS}$ application. The reason for the decrease in $\mathrm{pH}$ can be explained by the release of fatty acids from biological materials in the sludge after hydrolysis by sonication (Fig. 8). This decrease in $\mathrm{pH}$ is within the range that anaerobic organisms can tolerate. Therefore, it can be concluded that sonication will not adversely affect the physico-chemical properties of wastewater; it could even provide improvements which help the operation of anaerobic processes.

Cavitational collapse produces turbulence and high shearing phenomena in the liquid phase. These events disrupt particles and reduce the size during sonication (Gibson et al., 2009). When particles of material in a liquid suspension are subjected to sonication, large particles are exposed to surface erosion or particle size reduction occurs (Kuldiloke et al., 2002) The reduction in particle size generally eases the hydrolysis of solids, since available particle surface area increases for hydrolysis. The result is an accelerated and enhanced degradation of the organic fraction of the solid phase

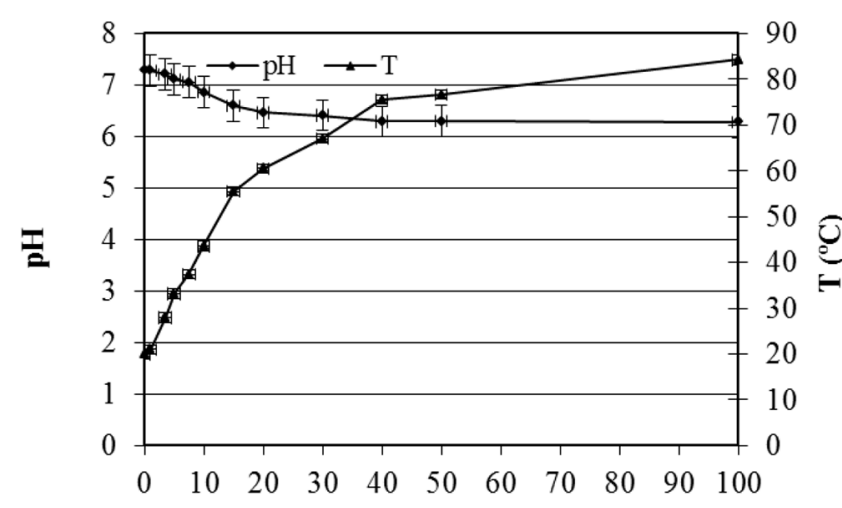

Specific Energy (MJ/kg TS)

Figure 2. The variation of temperature and $\mathrm{pH}$ of sludge with specific energy

Table 2. Particle size changes for different specific energies.

\begin{tabular}{lccccc}
\hline & \multicolumn{5}{c}{ Particle Size $(\mu \mathrm{m})$} \\
\cline { 2 - 6 } $\begin{array}{l}\text { Specific } \\
\text { kg TS) }\end{array}$ & $\begin{array}{c}\text { Surface } \\
\text { weighted } \\
\text { mean } \\
\text { D }[3,2]\end{array}$ & $\begin{array}{c}\text { Volume } \\
\text { Weighted } \\
\text { mean } \\
\text { D }[4,3]\end{array}$ & $\mathrm{d}(0.1)$ & $\mathrm{d}(0.5)$ & $\mathrm{d}(0.9)$ \\
\hline 0 & 71.53 & 148.58 & 53.23 & 118.10 & 255.03 \\
3.5 & 10.32 & 44.62 & 5.24 & 22.18 & 96.14 \\
7.5 & 8.31 & 46.35 & 4.19 & 17.26 & 102.62 \\
15 & 6.05 & 44.88 & 2.73 & 14.48 & 119.99 \\
30 & 6.06 & 46.12 & 2.73 & 14.54 & 122.54 \\
50 & 6.14 & 79.30 & 2.59 & 22.24 & 250.52 \\
100 & 6.04 & 63.83 & 2.52 & 24.31 & 155.20 \\
\hline
\end{tabular}

(Muller, 2003). Although particle size distribution shows the sludge disintegration, this parameter is not efficient for process optimization (Muller et al., 2004). Table 2 shows the particle size changes for different specific energies, demonstrating that $10 \%, 50 \%$, and $90 \%$ of particles (in volume) having a diameter lower or equal to $d(0.1), d(0.5)$, and $d(0.9)$, respectively. Particle size in sludge was reduced due to ultrasonic pre-treatment and higher reductions were obtained in ultrasonic pre-treated sludge with high specific energies comparing to that in raw sludge.

For $30 \mathrm{MJ} / \mathrm{kg} \mathrm{TS}$, a $70 \%$ particle size reduction was recorded based on the volume weighted mean $(\mathrm{D}[4,3])$. Ultrasonic treatment caused formation of many fine particles, which is not beneficial for sludge conditioning; the high CST values were recorded with increasing specific energy up to $15 \mathrm{MJ} / \mathrm{kg}$ TS. Then CST values decreased above $15 \mathrm{MJ} / \mathrm{kg}$ TS (Fig. 8). High temperature may cause a thermal conditioning effect for sludge. The lower particle size reduction above $30 \mathrm{MJ} / \mathrm{kg}$ TS supported this result.

The effects of ultrasonic pre-treatment on supernatant characteristics of sludge 
Disintegration causes disruption of microbial cells in the sludge, thereby destroying the cell walls (Vranitzky et al. (2005)). The destruction of floc structure and disruption of cells results in the release of organic sludge components into the liquid phase. These components exist in a dissolved state, e.g., components of intracellular water, or can be liquified (Muller et al., 2004). Ultrasonic pre-treatment was very effective and contributed to the rapid initial increase of nitrogen and phosphorus. As shown in Figure 3, phosphorus and nitrogen were released to the sludge supernatant in a few minutes due to ultrasonic pre-treatment.

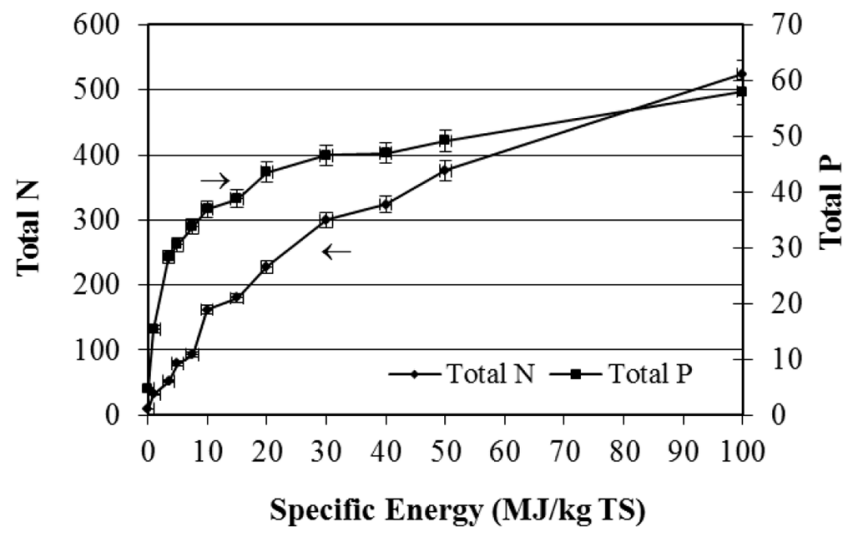

Figure 3. Variation of total $\mathrm{N}$ and total $\mathrm{P}$ in the sludge supernatant with specific energy

Most of the phosphorus in the supernatant existed in the form of organic products. Nitrogen concentration in the supernatant increased with increasing specific energy. Nitrogen and phosphorus concentrations in the sludge supernatant was increased from $9 \mathrm{mg} / \mathrm{L}$ to 524 $\mathrm{mg} / \mathrm{L}$ and $4.8 \mathrm{mg} / \mathrm{L}$ to $58 \mathrm{mg} / \mathrm{L}$ for the highest specific energy of $100 \mathrm{MJ} / \mathrm{kg} \mathrm{TS}$, respectively.

Oil in the sludge is an important factor which interferes with the anaerobic digestion performance. Ultrasonic treatmentmay help demulsification of oiland then remove the adverse effect of oil on the anaerobic bio-process (Stack et al., 2005). Therefore, the effect of ultrasonic pre-treatment on oil concentration in the sludge supernatant was investigated. The variations of oil concentrations in the sludge supernatant with SE are depicted in Figure 4. There was a substantial increase in oil concentration when the specific energy was increased up to $40 \mathrm{MJ} / \mathrm{kg}$ TS. For higher specific supplied energies, oil removals were nearly constant. Increasing oil concentration in the sludge supernatant may be explained by increasing the sludge solids solubilization with ultrasonic pre-treatment. Oil which is bound to the sludge solids was released to the liquid phase due to solubilization of sludge solids with ultrasonic pre-treatment.

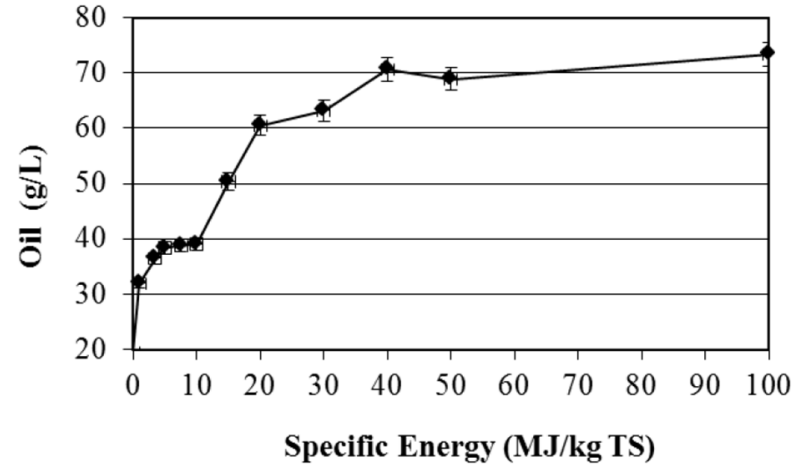

Figure 4. Variation of oil in the sludge supernatant with specific energy

\section{The effects of ultrasonic pre-treatment on anaerobic sludge bio-processing}

The anaerobic digestion process is achieved through several stages: hydrolysis, acidogenesis, and methanogenesis. Hydrolysis is the rate-limiting stage for waste activated sludge degradation (Apples et al., 2008). In order to improve the rate of hydrolysis and anaerobic digestion performance, disintegration was developed as the pre-treatment process of sludge to accelerate the anaerobic digestion and to increase the degree of stabilization (Bougrier et al., 2005). Increase of the stabilization degree of sludge with the disintegration process provides less sludge production, more stable sludge, and more biogas production compared to the classical anaerobic digestion. A BMP assay was carried out to assess the feasibility of using ultrasonic pre-treatment in order to improve the anaerobic biological degradation of biological sludge. The BMP assay, in which cumulative methane production was monitored, was applied to both raw meat processing sludge and pre-treated sludge at the optimum condition based on the DD parameter (30 $\mathrm{MJ} / \mathrm{kg} \mathrm{TS})$ and at the highest SE application (100 MJ/ kgTS) for comparison purposes. Cumulative methane productions in serum bottles were monitored for 40 days (continued until the gas production ceased) and the results show that ultrasonic pre-treatment of meat processing sludge may be a good alternative for improving the anaerobic degradation (Fig. 5). The methane production volume was the highest for 30 $\mathrm{MJ} / \mathrm{kgTS}$ and it was the lowest for raw sludge. While the methane volume for raw sludge was only 121 $\mathrm{mL}$, the methane volume for sonicated sludge with the specific energy of $30 \mathrm{MJ} / \mathrm{kg}$ TS was $287 \mathrm{~mL}$ at the end of the 40 days of incubation. 2.4 times higher methane production in sonicated sludge was obtained compared to the raw sludge in this application. For the 
highest SE of $100 \mathrm{MJ} / \mathrm{kg}$ TS, 2.0 times higher methane production was obtained. Since the disintegration degree obtained at $100 \mathrm{MJ} / \mathrm{kg}$ TS is lower than that of $30 \mathrm{MJ} / \mathrm{kg}$ TS (Fig. 1), it is acceptable to obtain lower methane production at the highest SE.

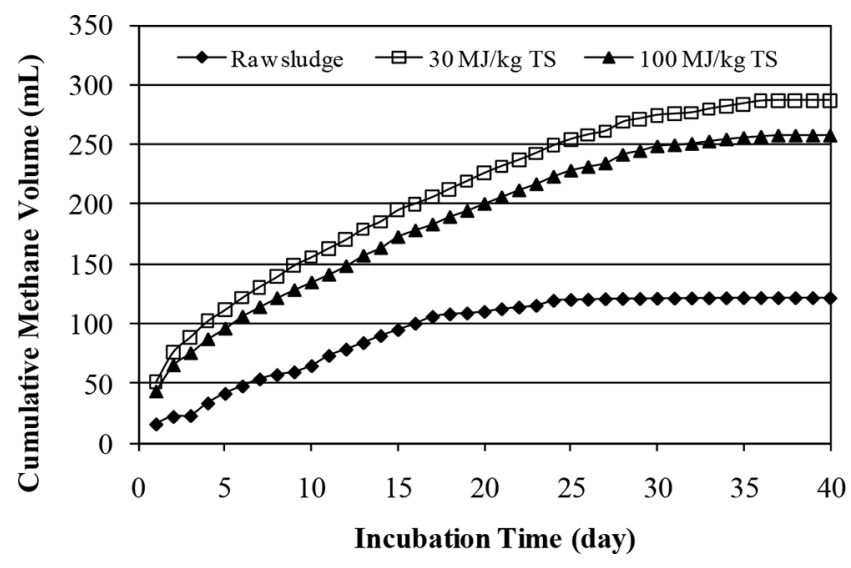

Figure 5. Results of the BMP test

Cell lysis transferring cell content into the medium is the first stage and breakdown of the extracellular polymeric substance (EPS) fraction in the sludge is the second stage of flock disintegration. Cell lysis leads to release of protein content into the liquid phase of sludge in the first stage of disintegration. In the second stage, disintegration enhances the degradation of extracellular polymeric substances (EPS) and the protein content of sludge decreases. Figure 6 shows the variation of protein concentration with SE. There was a slight decrease in protein concentration to $9.9 \%$ when specific energy was increased up to $5 \mathrm{MJ} / \mathrm{kg}$ TS. Further increase in SE application provided substantially better protein degradation. The highest decrease in protein concentration of $97.5 \%$ was obtained for the highest SE application of $100 \mathrm{MJ} / \mathrm{kg}$ TS. This value was recorded as $72.5 \%$ for optimum condition based on the DD parameter (30 MJ/kg TS of specific energy). The main purpose of disintegration is the elimination of the hydrolysis step to accelerate the anaerobic degradation. Results show that protein hydrolysis was performed successfully by ultrasonic pre-treatment.

Another indicator of the elimination of the hydrolysis step is volatile fatty acid formation in the sludge. Total volatile fatty acid (TVFA) analysis was carried out to assess the feasibility of using ultrasonic pre-treatment in order to improve the anaerobic biological degradation of meat processing sludge. Volatile fatty acid formation was not observed until $20 \mathrm{MJ} / \mathrm{kg}$ TS. Further increase in SE application substantially increased TVFA content in the sludge. For the highest SE application, $923 \mathrm{mg} / \mathrm{L}$ TVFA was obtained (Fig.7).

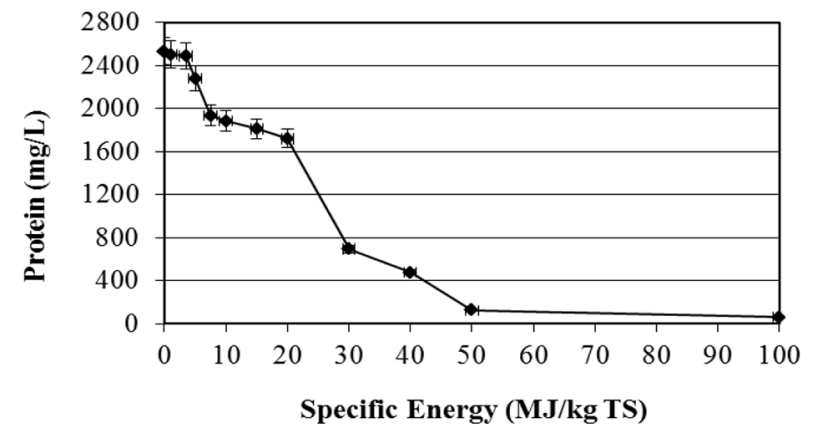

Figure 6. Variation of protein content of sludge with specific energy

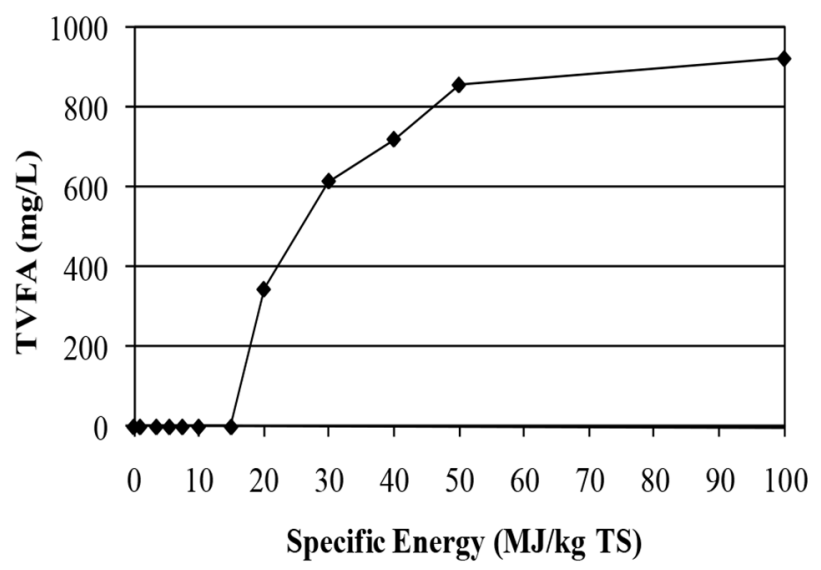

Figure 7. Variation of total volatile fatty acids content of sludge with specific energy

\section{The effects of ultrasonic pre-treatment on sludge filterability}

CST is a quick and simple method to evaluate the filterability of sludge. This method neglects the shear effect on sludge, and it cannot determine dewaterability differences between dewatering processes, but gives an approach to the dewatering capacity of sludge (Meeten et al., 1995). CST variations versus applied specific energy are given in Figure 8. CST gradually increased during the ultrasonic pre-treatment. CST results showed that ultrasonic pre-treatment deteriorates the filterability of biological sludge. Sludge filterability was also related to the sludge disintegration degree (Huan et al., 2009; Erden and Filibeli, 2010).

Correlation between CST and DD was examined using the Microsoft-Excel Statistical Correlation function and the correlation coefficient $\left(\mathrm{R}^{2}\right)$ was found to have a very high value of $97 \%$. When the sludge disintegration degree was too low, sludge filterability was not significantly affected. When the sludge disintegration degree was high, many fine particles were produced, which led to increasing biosolid 


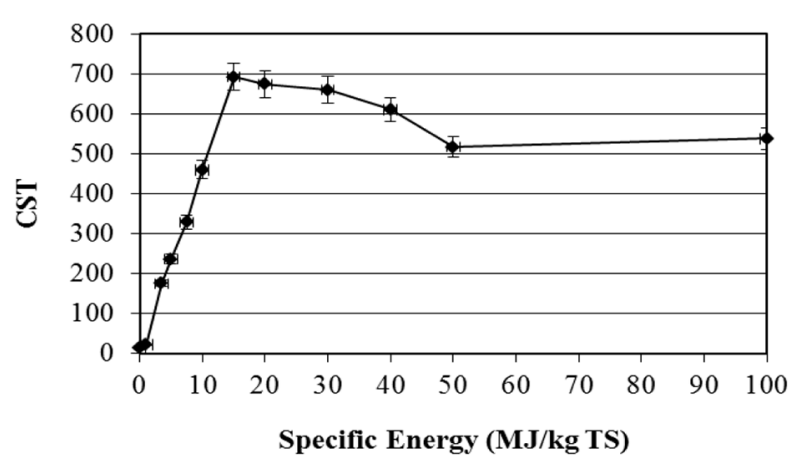

Figure 8. Variation of CST with specific energy

resistance to dewatering. The little decrease in CST above $20 \mathrm{MJ} / \mathrm{kg}$ TS may be related to the thermal effect of sonication. Increasing temperature with increasing SE may play a conditioner role for sludge and it led to a decrease in the biosolid resistance to dewatering.

\section{CONCLUSIONS}

Sludge taken from a meat processing wastewater treatment plant is either not biodegradable or very slow to degrade in biological processes. This investigation deals with disintegration of meat processing sludge with ultrasonic treatment. The disintegration degree of sludge increased with increasing specific energy. Besides, ultrasonic pre-treatment is an effective method for meat processing sludge disintegration. $30 \mathrm{MJ} / \mathrm{kg}$ TS of supplied energy is efficient for sludge solubilizaton. Ultrasonic pre-treatment led to a change of the physico-chemical characteristics of sludge. For instance, temperature increased and $\mathrm{pH}$ decreased gradually with increasing specific energy. Disintegration causes disruption of microbial cells in the sludge, thereby destroying the cell walls. The destruction of floc structure and disruption of cells results in the release of organic sludge components into the liquid phase. Thus, the sludge supernatant characteristics were also affected by the ultrasonic pre-treatment. For $30 \mathrm{MJ} / \mathrm{kg} \mathrm{TS}$, oil content, total nitrogen (TN) and total phosphorus (TP) in the sludge supernatant increased by 3.8 times, 58 times, and 12 times, respectively. Biochemical methane potential (BMP) results obtained in this study suggest that ultrasonic pre-treatment led to an increase in the anaerobic biodegradability of biological sludge. 2.4 times higher methane production in sonicated sludge (30 MJ/kg TS) was obtained compared to the raw sludge. Protein and oil hydrolysis was also performed successfully by ultrasonic pre-treatment. Furthermore, CST results showed that ultrasonic pre-treatment deteriorates the filterability of biological sludge. On the other hand, DD results were in good agreement with CST results. Low disintegration degree in sludge did not significantly affect the filterability. In contrast, when high disintegration degree was achieved, many fine particles were produced and it caused the deterioration of sludge filterability.

\section{ACKNOWLEDGEMENT}

The author expresses sincere appreciation to The Scientific and Technological Research Council of Turkey (TUBITAK) for supporting the study under award \#105Y337: Sludge Disintegration using Advanced Oxidation Processes.

\section{REFERENCES}

Anteneh, M., Cong, S., Sen, T. K., Ang, M., and Kayaalp, A., Effect of ultrasonic, microwave and combined microwave-ultrasonic pre-treatment of municipal sludge on anaerobic digester performance, Water, Air, \& Soil Pollution, 2, 7-11 (2013).

APHA, AWWA, WEF. 2005. Standard Methods for the Examination of Water and Wastewater. $21^{\text {st }} \mathrm{edn}$, American Public Health Association/American Water Works Association/Water Environment Federation. Washington DC, USA.

Apples, L., Baeyens, J., Degreve, J., and Dewil, R., Principles and Potential of the Anaerobic Digestion of Waste-activated Sludge, Progress in Energy and Combustion Science, 34, 755-781 (2008).

Bougrier, C., Albasi, C., Delgenés, J.P., Solubilisation of Waste-activated sludge by Ultrasonic Treatment, Chemical Engineering Journal, 106, 163-169 (2005).

Bougrier, C., Albasi, C., Delgenés, J.P., Carrére, H., Effect of Ultrasonic, Thermal and Ozone Pre-Treatments on Waste Activated Sludge Solubilisation and Anaerobic Biodegradability, Chemical Engineering and Processing, 45, 711-718 (2006).

Erden, G., Filibeli, A., Ultrasonic pre-treatment of Biological Sludge: Consequences on Disintegration, Anaerobic Biodegradability, and Filterability, Journal of Chemical Technology and Biotechnology, 85, No.1, 145-150 (2010).

Frolund, B., Palmigren, R., Keiding G. K., Nielsen P. H., Extraction of Extracellular Polymer from Activated Sludge using a Cation Exchange Resin, Water Research, 30, No.8, 1749-1758 (1996). 
Gibson, J.H., Hon, H., Farnood, R., Droppo, I. G., Seto, P., Effects of Ultrasound on Suspended Particles in Municipal Wastewater, Water Research, 43, No.8, 2251-2259 (2009).

Goodwin, J.A. S,Forster, C.F., A Further Examination into the Composition of Activated Sludge Surfaces in Relation to Their Settlement Characteristics, Water Research, 19, No.4, 1038-1046 (1985).

Huan, L., Yiying, J., Maha,r R.B.,Zhiyu, W., Yongfeng, N., Effects of Ultrasonic Disintegration on Sludge Microbial Activity and Dewaterability, Journal of Hazardous Materials, 161, 1421-1426 (2009).

Kavitha, S., Rajesh B.J.,IvinShaju, C.D., Kaliappan, S., Ick, TY., Fenton Mediated Ultrasonic Disintegration of Sludge Biomass: Biodegradability Studies, Energetic Assessment, and Its Economic Viability, Bioresource Technology, 221, 1-8 (2016).

Kuldiloke, J., Effect of Ultrasound, Temperature and Pressure Treatments on Enzyme Activity and Quality Indicators of Fruit and Vegetable Juices. Ph.D. Thesis, Technical University of Berlin (2002).

Luste, S., Luostarinen, S., Sillanpaa, M., Effect of Pretreatments on Hydrolysis and Methane Production Potentials of by-products from Meat-processing Industry, Journal of Hazardous Materials, 164, 247-255 (2009).

Meeten, G.H., and Smeulders, J.B.A.F., Interpretation of Filterability Measured by the Capillary Suction Time Method, Chemical Engineering Science, 50, No.8, 1273-1279 (1995).

Muller, J.A., Disintegration as a Key-Step in Sewage Sludge Treatment, Water Science and Technology, 41, No.8, 123-130 (2000).

Muller, J.A., Conditioning, Thickening and Dewatering of Mechanically Disintegrated Excess Sludge,Separation Science and Technology, 38, No.4, 889-902 (2003).

Muller, J.A., Winter, A., Strünkmann, G., Investigation and Assessment of Sludge Pre-treatment Processes, Water Science and Technology, 49, No.10, 97-104 (2004).

Ning, X., Wenxiang W.,Pingfangb, H., Xiaoping, L., Effects of Ultrasound on Oily Sludge Deoiling, Journal of Hazardous Materials, 171, 914-917 (2009).

Owen, W.F., Stuckey, D.C., Healy, J.B., Young, L.Y., McCarty, P.L., Bioassay for Monitoring Biochemical Methane Potential and Anaerobic Toxicity, Water Research, 13, 485-492 (1979).
Pham, T.T.H., Brar, S.K., Tyagi, R.D., Surampalli, R.Y., Ultrasonication of Wastewater SludgeConsequences on Biodegradability and Flowability, Journal of Hazardous Materials, 163, 891-898 (2009).

Razo-Flores, E., Luijton, M., Donlon, B.A., Lettinga, G., and Field, J.A. Biodegradation of Selected Azo Dye under Methanogenic Conditions, Water Science and Technology, 36, 65-72 (1997).

Rico, J.L., Garcia, H., Rico, C., Tejero, I. 2007. Characterization of Solid and Liquid Fractions of Dairy Manure with Regard to their Component Distribution and Methane Production. Bioresource Technology. 98: 971-979.

Riesz, P., Berdahl, D., Christman, L., Free Radical Generation by Ultrasound in Aqeous and Nonaqeous Solutions, Environmental Health and Perspective, 64, 233-252 (1985).

Sahinkaya, S., Disintegration of Municipal Waste Activated Sludge by Simultaneous Combination of Acid and Ultrasonic Pretreatment, Process Safety and Environmental Protection, 93, 201-205 (2015).

Show, K.Y., Mao, T., and Lee D.J., Optimization of Sludge Disruption by Sonication, Water Research, 41, 4741 - 4747 (2007).

Speece, R E., Anaerobic Biotechnology for Industrial Wastewaters, Published by Arche Press. (1996).

Stack, L.J., Carney, P.A., Malone, H.B., Wessels, T.K., Factors Influencing the Ultrasonic Separation of Oil-in-water Emulsions, Ultrasonic Sonochemistry, 12,153-160 (2005).

Tian, X., Trzcinski, A:P.,Lin, L.L., Ng, W.W., Impact of Ozone Assisted Ultrasonication Pre-Treatment on Anaerobic Digestibility of Sewage Sludge, Journal of Environmental Sciences, 33, 29-38 (2015).

Tiehm, A., Nickel, K., and Neis, U., The Use of Ultrasound to Accelerate the Anaerobic Digestion of Sewage Sludge, Water Science and Technology, 36, No.11, 121-128 (1997).

Xie, B., Liu, H., Yan, Y., Improvement of the Activity of Anaerobic Sludge by Low-intensity ultrasound, Journal of Environmental Management, 90, 260264 (2009).

$\mathrm{Xu}, \mathrm{H} ., \mathrm{He}, \mathrm{P} ., \mathrm{Yu}, \mathrm{G} .$, Shao, L., Effect of ultrasonic pretreatment on anaerobic digestion and its sludge dewaterability, Journal of Environmental Sciences, 23, No.9, 1472-1478 (2011).

Vranitzky, R., Lahnsteiner, J., Sewage Sludge Disintegration using Ozone - A Method of Enhancing the Anaerobic Stabilization of Sewage 
Sludge, VA TECH WABAH, R\&D Process Engineering. Siemensstrasse 89, A-1211 Vienna, Austria (2005).

Wang, F., Wang, Y., Ji, M., Mechanisms and Kinetics Models for Ultrasonic Waste Activated Sludge Disintegration, Journal of Hazardous Materials, B123, 145-150 (2005).

Yeneneh, A.M., Kayaalp, A., Sen, T.K., Ang, H.M., Effect of Microwave and Combined MicrowaveUltrasonic Pretreatment on Anaerobic Digestion of Mixed Real Sludge, Journal of Environmental Chemical Engineering, 3, 4, 2514-2521 (2015).
Yeneneh, A. M., T. K.Sen, H. M. Ang and A. Kayaalp, Optimization of Microwave, ultrasonic and combined microwave-ultrasonic pretreatment conditions for enhanced anaerobic digestion, Water, A ir, Soil Pollution, 228, 1, 1-13 (2017).

Zhou, C. Huang, X. Jin, Y. and Li, G., Numerical and experimental evaluation of continuous ultrasonic sludge treatment system, Ultrasonics, 71, 143-151 (2016).

Zielewicz, E., Effects of ultrasonic disintegration of excess sewage sludge, Applied A coustics, 103, 182-189 (2016). 
